\title{
Introduction to the Research Handbook of Diversity and Careers
}

\author{
Adelina M. Broadbridge and Sandra L. Fielden
}

Diversity is now a globally recognized concept in management studies (Özbilgin and Chanat, 2017). Examining diversity in organizations is about exploring hierarchical organized dichotomies, and when considering the diversity dimension of organizations we often find implicit assumptions about which categories are viewed as the norm and which are considered the opposite or other. Classical examples are the male norm and the female other (Bendl, 2005), or the perspective of the white majority as the norm and the black minority as the opposite (Holvino, 2008). Organization studies are not only dominated by the perspective of white middle-class heterosexual able-bodied men, but also by the perspective of Western organizations. This may suggest that research in organizations with an American or European descent or location is the basis for universal knowledge about organizations that can be applied all over the world, which of course is misguided. Social phenomena in organizations are often explored and explained from the perspective of these hegemonic groups (Hearn, 2004). To attain knowledge that incorporates the perspective of the whole organization, organization studies need to incorporate the empirical perspectives of marginalized groups.

\section{DEFINING DIVERSITY IN THE WORKPLACE}

Managing Diversity initiatives seek to fully develop the potential of each employee and turn the different sets of skills that each employee brings into

a business advantage. Through fostering the difference, team creativity, innovation and problem-solving can be enhanced. The focus is therefore, much more on the individual rather than the group. Having a diverse workforce not only enables organisations to understand and meet customer demand better, but also helps attract investors and clients, as well as reduce the costs associated with discrimination.

(Davidson and Fielden, 2003, pp. xxi) 
However, just appealing to employers to recognize the value of diversity of each individual employee is not likely to change much in terms of how people are treated, rewarded or recognized in the workplace (Tatli and Özbilgin, 2012). In other words, barriers to recruitment, wage discrimination, job segregation and a lack of career progression will not simply disappear because of normative demands and expectations which are driven by volunteerism on the part of organizations rather than coercive legal matters (Wettstein, 2009).

Recognition that coercive legislation is required in order to address the lack of representation and discrimination within organizations of minority groups led to the introduction of legislation in many countries around the world, for example, Australia, Europe, New Zealand, Scandinavian, the United States of America (USA) and the United Kingdom (UK). Much of this new legislation is more comprehensive and amalgamates previous disparate legislation, for example the UK Equality and Diversity Act (2010) replacing the previous anti-discrimination laws (that is, Sex Discrimination Act 1975, Race Relations Act 1976, and Disability Discrimination Act 1995) with a single Act. As with much of the recent legislation, the new Act introduced the notion of 'protected characteristics' with the aim to strengthen the legislation in regard to the specific groups: for example, age, disability, gender reassignment, marriage and civil partnership, race, religion or belief, sex and sexual orientation.

Not all legislation covers these aspects; depending on the religious and cultural background of the country, they may still have no legislation at all. In addition, some diverse characteristics have received more research attention than others: for example, sex and race (Bell et al., 2011). In this Handbook we pay attention to eight diverse characteristics and focus on individuals' career development. This of course does not cover all aspects of diversity, such as social class, but does provide a focus on the categories given the most coverage in global legislation.

Careers were originally presented as linear (Super, 1957), where a person worked in one or two companies for the whole of their career, gradually working their way up the organization. While this career pattern has received considerable attention, it is also subject to criticism; not least due to the fact it does not adequately address the position of women's careers. However, the linear model still appears to be upheld and rewarded in many twenty-first-century organizations (e.g., King et al., 2017; Zimmerman and Clark, 2016), thus making top positions very competitive to achieve. Nevertheless, to account for differing career patterns, a series of other models arose in the last quarter of the twentieth century. So, for example, we see the recognition of multidirectional careers (Baruch, 2004; Brousseau et al., 1996; Peiperl and Baruch, 1997; 
Walker, 1992) which may include lateral, spiral and downward movements, as well as 'patchwork' (Halryno, 2009) 'post corporate' (Peiperl and Baruch, 1997) and 'portfolio' careers (Mallon, 1998). Moreover, the 'protean' (Hall, 1976, 1996) and 'boundaryless' (Arthur, 1994) careers assume that individuals, not the organizations, have the power and movement to control their own career destinies; which is interesting, given that diversity also focuses on the individual rather than the organization.

Sullivan and Baruch (2009) assert that dramatic changes in the economic environment, such as globalization and corporate restructuring, as well as personal aspirations, such as work-life balancing, have had a major impact on how people experience their careers. Baruch and Vardi's (2016) examination of contemporary careers provides an interesting account of how the realities of careers can result in bleak opportunities, involuntary unemployment and redundancies. This, they argue, can result in false hope, with positive ideas of careers being dashed, and leading to frustration and reduced ambitions, which in turn lead to failure and missed opportunities. The effects of this on diverse groups requires further investigation as they may be especially vulnerable to cut-backs and reduced opportunities in such an austere environment. While individuals might have more control over their careers than in the past, there remain various additional factors that can impede the careers of those with diverse characteristics. These are the subject of this Handbook.

\section{APPROACH TO THE HANDBOOK}

This Handbook takes an international look at current thinking, practices and initiatives that reflect the position of the career development of diverse groups. It seeks to present current research, practice, ideas and developments, and considers major issues and future directions in the field of career development for diverse groups. It also provides an up-to-date review of the current global perspectives, bringing together the foremost scholars in the field. The Handbook covers a wide range of pertinent issues that impact on the careers of diverse groups, covering all of the well-researched diversity headings, as well as including the less well-covered areas such as appearance, sexuality and religion. Each chapter has a general structure in common, that is, introduction, theory and concepts, and the practical implications and recommendations that have worldwide transferability. The authors represent a wide range of countries, including Australia, Austria, Finland, India, Italy, New Zealand, Pakistan, the UK and the USA. As we do not recognize any one 
category as more important than another, the sections are presented in alphabetical order.

\section{Part I: Age}

Attention to the issue of age and diversity has grown in over recent years because of the population changes across the world. In many countries, population shifts are now evident as a result of falling birth rates and increasing life expectancies. Falling birth rates have led to a shortage of young people in many labour markets, although competition for jobs among young people can be fierce. Globally, the number of people aged 60 and over is expected to double by 2050 and triple by 2100 (United Nations, 2015). As the population ages, so this has a resultant impact on careers and retirement plans. The infrastructure to enable people to retire at a certain age has collapsed in many countries, and as a result people are now working longer: those from Generation $\mathrm{Y}$ and $\mathrm{Z}$ have expectations to work beyond their seventies. The removal of a default retirement age has led to a questioning and rethinking of the meaning of retirement, with some people having encore careers (Murphy and Volpe, 2015; Simpson et al., 2012), where they take on paid work in later life that has greater personal meaning and social impact, or enables a more balanced lifestyle.

Age cuts across the various stages of career development from entry to exit levels and retirement, and ageism describes the negative stereotypes and discrimination shown towards people because of their age. While this often is directed towards older people, it can be applied to people of any age category. Kumra and Manfredi (2012) claim that both younger and older employees believe they have experienced age discrimination in recruitment and promotions; they show how age discrimination impacts upon both the individual and the organization. At an individual level this can result in material disadvantage, social exclusion and loss of selfesteem and dignity; at an organizational level it can undermine the morale, motivation and performance of employees. Kirton and Greene (2016) argue that there are more myths and stereotypes underpinning age discrimination than hard facts. For example, common stereotypes are that older people are resistant to change, difficult to train, less productive and inflexible; despite other evidence that shows the many positive aspects of employing older people (Mountford and Murray, 2015).

The issue of ageism can intersect in various ways with other diversity dimensions. For example, often women in the workplace are discriminated by their age more than men (Duncan and Loretto, 2004), and women may also encounter the triple bias of gender, age and appearance 
(Granleese and Sayer, 2005). Also, women in later life have to deal with other issues that might impact upon their careers, such as the menopause, body image and sexuality, the empty nest and the declining health of their parents (Etaugh, 2013).

\section{Chapters on age}

Chapter 1 by Emma Parry focuses on careers across the lifespan and the impact of age on career outcomes by looking at the different perspectives commonly used in examining the impact of age. She concentrates on the three main approaches: maturation effects, career stage and preference, and the shared values and experiences of a generation. In doing so she moves away from traditional career theory that views the development of career as a linear process, instead emphasizing the personal and contextual factors which drive the career experience.

Linda McKie and Marjut Jyrkinen (Chapter 2) take a more focused exploration of the intersection between age and gender in a cross-cultural examination of the mid-careers of women managers in Finland and Scotland. This empirically based chapter demonstrates the failure of legislation to prevent the continuing overt and covert discrimination experienced by women regardless of country, sector or workplace, thereby highlighting the dissonance between rhetoric and practice.

The later stages of career development are explored by Judy McGregor (Chapter 3), who considers the layers of discrimination produced by multiple identities. She looks at the impact of prolonged life expectancy on careers in terms of cumulative discrimination, and considers how global and national legislation in New Zealand has taken account of the ageing workforce. She stresses the need to more firmly locate older women's career development in the context of equal employment opportunities and anti-discrimination frameworks.

Finally, Frances Tomlinson (Chapter 4) looks at the end stage of careers, with a focus on the gendered aspects of retirement. She examines the relationship between longer life expectancy, extended working lives and changes to the retirement age, using empirical research to highlight the issues of choice, control and constraint when facing retirement.

\section{Part II: Appearance}

It seems incredible that one's appearance can have an impact on one's career development, yet it does, and often through implicit bias. First impressions can be heavily influenced by attire (Howlett et al., 2015), with dress and appearance regarded as very important in the workplace (Karl et al., 2013). Even hair colour can impact on the perceptions of 
workers, especially women, with stereotypes around the blonde and grey images. Appearance and image also influence career success (Yates et al., 2016): for example, appearance has been shown to influence workplace promotions and salary decisions (Peluchette et al., 2006). However, appearance can be used strategically to manage an individual's body image (Frith and Gleeson, 2008), their self-perceptions (Peluchette and Karl, 2007), as well as the impression of others in the workplace (Peluchette et al., 2006). Jyrkinen (2014) found that women managers felt pressured about their appearance in order to be successful in their careers; yet, interestingly, being sexually attractive can be regarded as unprofessional for women (Kelan, 2013). Appearance discrimination is current and widespread and, as the chapters in this section show, appearance can have very real impacts on how employees are perceived. While not a protected category, appearance is a real issue with regards to discrimination, and has given rise to terms such as 'lookism' (Cavico et al., 2012; Warhurst et al., 2012), 'looks based appearance' (Bruton, 2015) and 'aesthetic labour' (Nickson, Chapter 5). Moreover, appearance has become increasingly important to some companies in their efforts to market the right image to their clientele; while a direct correlation between employee appearance and customer perceptions of service quality has been observed (Karl et al., 2013). So we see many customerfacing roles where appearance is all part of the service and the brand image to be portrayed.

Appearance can also include body modifications such as tattoos and piercings, and companies may have strict rules about visible modifications. Visible body art can have a potentially negative impact on employment chances, with tattoos being associated with lower hireability ratings for customer-facing roles than piercings (Timmings et al., 2017). Nevertheless, facial piercings carry significant stigma (Swami et al., 2012) and can have a negative effect on employability. Timmings et al. (2017) also found body modifications to carry a greater stigma among men in comparison to women, with those on men potentially being perceived as more threatening. Hence, how one looks can affect the recruitment and career progression decisions of employers, with McElroy et al. (2014) arguing that the chances of being offered a job are lowered if the applicant is physically unattractive, facially disfigured, obese, or unfashionably or inappropriately dressed.

\section{Chapters on appearance}

Dennis Nickson starts Part II by looking at the general concept of appearance and its impact on career development and progression (Chapter 5). He explores the concept of 'aesthetic labour', highlighting how 
hiring on the basis of looks is now a well-established strategy in a range of occupations and organizations, particularly within the service sector. The chapter considers the legal and ethical implications of employers often hiring on the basis of appearance, including attempts in some areas to prevent appearance discrimination.

Chapter 6 examines a much more specific area of appearance, that is, size. This is a highly contentious issue and Patricia Roehling, Mark Roehling and Austin Elluru begin by looking at the biases that underpin size discrimination. They then show how those biases can impact on the recruitment, promotion, remuneration, job assignment and career trajectory of individuals deemed to be overweight or obese. Their chapter demonstrates how stereotyped terms to describe those who are overweight continue to be perpetuated in Western society.

In the 1990s there was a lot of media coverage of 'power dressing' for women, and it is interesting that Joy Van Eck Peluchette and Katherine Karl (Chapter 7) argue that having the 'right' look can have a significant impact on perceptions and outcomes for women's career success. Their focus is on clothing, body adornments and body modification, and they explore how women walk a tightrope between not looking too feminine, too masculine or too sexy. They look at ways women attempt to increase their physical attractiveness through attire, make-up, hair colour, fragrance and even nail colour as a means to manage the impression of others.

While we might be excused for thinking that attractive people 'have it all', Stefanie Johnson, Ksenia Keplinger, Jessica Kirk and Elsa Chan (Chapter 8) show the downsides of attractiveness, and how attractiveness can be a disadvantage for professional women (yet not men) in recruitment, promotion and compensation. They also highlight how attractive women may be objectified and subject to greater sexual harassment, and how attractiveness can provoke greater same-sex competition; all of which can cause problems in the various stages of their careers.

\section{Part III: Disability}

Disability is a wide-ranging protected category which encompasses both physical and mental disabilities; Nafukho et al. (2010) categorize disabilities as physical, sensory, emotional and cognitive. Of the protected characteristics, disability is arguably the most heterogeneous group, given the amount of different disabilities people may have, and so the career development of people with disabilities is a complex process. Discrimination based on disability is widespread and, while many disabilities are visible, many are invisible and this can make career-based discrimination 
on disability grounds even more insidious. Disabled people may find that their career paths suffer from various constraints, such as stereotyping stigmatization (Moore and Huberty, Chapter 9) and marginalisation (Kahn, Achola and Povenmire-Kirk, Chapter 11), which can limit their access to education and training, in addition to inhibiting their careers. Often non-disabled people react in awkward and derisory ways to disabled people and this too may have an effect on the disabled person's career. Fujimoto et al. (2014) claim that disabled people are classified as outgroup members, creating a culture of ignorance, misconception, stereotyping and stigma. Employers can lack understanding of the disability and there should be awareness training for managers and employees about disability issues. Unsurprisingly, far fewer people of working age with disabilities are employed compared to those who are not disabled. For example, in the UK in 2012, 46.3 per cent of working-age disabled people were in employment compared to 76.4 per cent of working-age non-disabled people (Office for Disability Issues, 2014). As well as unemployment, they are also more prone to underemployment and lower-waged positions with little opportunities for career advancement (Fujimoto et al., 2014). Working environments themselves can pose barriers to inclusion and the full participation of disabled people who suffer discriminatory treatment or lack of support. Unsurprisingly, some disabled people are reluctant to disclose their disability for fear of being discriminated against (Reynolds et al., 2001).

\section{Chapters on disability}

Mark Moore and Lana Huberty begin Part III with Chapter 9, by exploring the impact of organizational leadership and how it affects diversity orientation and the managing of diversity relative to individuals with disabilities. They go on to consider how disability diversity orientation theory can increase the employment and career opportunities for people with disabilities, and assert that diversity orientation is linked to the managing of disability diversity in work organizations.

Following on from this, Lauren Lindstrom, Kara Hirano and Richie Thomas (Chapter 10) use a systems theory framework to present an overview of the career development process for individuals with disabilities. They take both an individual and a social perspective to explore the multiple interrelated systems that influence the complex process of careers development of people with disabilities.

A more focused perspective to disability is taken by Laurie Gutmann Kahn, Edwin Obilo Achola and Tiana Povenmire-Kirk (Chapter 11), who adopt an intersectionality approach to consider the barriers and unique experiences in the career development of young adults with disabilities. 
They explore the impact of stereotypes assigned to multiple identities, which shape the value systems within which career development occurs.

Intersectionality is the subject of the final chapter in Part III presented by Gemma Bend and Vincenza Priola (Chapter 12). They use empirical research to explore the work experiences of disabled women, highlighting their thoughts and feelings in relation to work, workplace interactions and career trajectories. Focusing on the three themes of experiences of discrimination, disability and career, and support in employment, they found that visual cues impact work experiences almost as much as the limitations that a physically disabled body presented.

\section{Part IV: Gender}

Women's and men's careers have taken on very different paths owing to traditional stereotypes of women's and men's place in the family and workplace. Many people believe that organizations are gender neutral, when in fact a masculine perspective and way of working dominates (Acker, 1990; Alvesson and Billing, 2009). The whole way that management is organised privileges men, and the ideal worker is still regarded as masculine (Benschop and Doorewaard, 2012; Billing, 2015). Successful management reflects organizational male cultural norms and hegemonic masculinity, and so is assumed to be consistent with characteristics traditionally valued in men (Kanter, 1977; Kerfoot and Knights, 1993; Schein, 1975, 2001; Wajcman, 1996, 1998). Organizations are also gendered spaces which establish and reproduce gendered regimes which impact on recruiting and promotion policies for management positions (Hannappi-Egger, 2015). Heilman et al. (2015) use the 'lack of fit' model to demonstrate how gender-based expectations result in different interpretations of the same behaviour and how stereotypes are reinforced. In many organizations, therefore, women continue to be treated less favourably than men (Eagly and Carli, 2007; Powell, 2012), are regarded as less competent (Heilman, 2001; Prime et al., 2008), are highly scrutinized in a way that does not apply to men (Eagly and Carli, 2007; Ryan and Haslam, 2005) and have to work harder than men (Mavin et al., 2015).

Life-stage events, such as motherhood, can have a profound influence on both the perception and the enactment of women's careers and career transitions (Lewis et al., 2015). Women's careers comprise more than work: they are embedded in women's larger life contexts, and families continue to be seen as liabilities in women's career development in organizations (O'Neil et al., 2013). As such, women face more hindrances and interruptions than men, and as a consequence their career paths are often different to those of men, as they juggle priorities 
(Maddox-Daines, 2016). As a consequence, several researchers have posited different career models so that gender can be accounted for. These models include 'rivers of time' (Powell and Mainiero, 1992), 'kaleidoscope' (Mainiero and Sullivan, 2005), 'career developmental phases' (O'Neil and Bilimoria, 2005) and 'labyrinth' (Eagly and Carli, 2007). Self-employment is also an alternative career model for women as it enables them to combine economic and family demands (Lewis et al., 2015); although the search for balance remains significant (Anderson and Vinnicombe, 2015).

However, women have made substantial advances in junior and middle management posts over the past 50 years. Success factor for women include support from bosses and being given challenging assignments early on in their careers (Holton, 2015), self-efficacy, the acquisition of human and social capital (Broadbridge, 2015), and the availability of flexible work arrangements (Levin et al., 2015). Nevertheless, an abundance of research reveals that women continue to be under-represented at the senior levels of management (Dubbelt et al., 2016; Haynes, 2017). At the most senior levels, research has shown how executive search consultants endorse and reproduce male dominance at the top of organizations (Bendl et al., 2015; Tienari et al., 2013).

Other barriers that impact on women's career development include being given less challenging high-profile assignments; receiving less feedback on their performance; receiving less training; having less access to networks and mentors or sponsors; experiencing more harassment and gender-based stereotypes; having inadequate career opportunities; experiencing tensions between private and work life; having less confidence and being too self-critical; combining work and family commitments; lack of career support and feedback; the competing demands of career and family; gender stereotyping and discrimination; gender and leadership styles; and the structure and culture of organizations (Agars, 2004; Broadbridge, 2008, 2009; Carli, 2015; Catalyst, 2010; Holgersson, 2013; Holton, 2015; Kumra, 2010; Oakley, 2000; Sealy and Singh, 2010; Vanderbroek, 2010; Wellington et al., 2003; Wood, 2009).

\section{Chapters on gender}

Thomas Calvard begins Part IV by using the rather neglected concept of 'imposter syndrome' to understand the internal influences created by a wide range of experiences on how women perceive themselves. He explains how those perceptions, underpinned by tendencies of, for example, self-doubt, self-criticism and insecurity, impact on their careers. He goes on to consider the particular types of experiences, associations and dilemmas shaping women's impostor experiences at work, as well as 
theories, examples and explanations of how they might affect their career development.

In Chapter 14, Sherry Sullivan and Shawn Carraher use the kaleidoscope career model (KCM) to capture how individuals are enacting their careers within a fluid, boundaryless workplace era. The model captures the complexities of both women's and men's careers. The authors focus on how different organizations have created cultures of authenticity, balance and challenge, the main components of the KCM to promote gender equity in the workplace.

Tanuja Agarwala (Chapter 15) specifically explores the impact of bullying on the career progression of women academics in India. Based on empirical research, she demonstrates how gendered bullying can manifest itself in the workplace. Various negative career challenges are reported, including denial or delay in promotions, not being assigned responsibility, exclusion from departmental committees, and withholding or selective sharing of information. She argues for organizational support to help mediate the long-term effects of the bullying behaviour.

Following on from this, Melissa Hynd and Adelina Broadbridge (Chapter 16) present an in-depth look at women's career experiences in the banking sector. Although the bank had introduced various initiatives to break the glass ceiling for women, some archaic views continue to dominate. Various respondents spoke about 'capital deficits' in their career, and some women continue to struggle with issues of confidence and self-promotion. The authors also conclude that there is a need to create a positive culture surrounding return to work and flexibility issues.

\section{Part V: Race}

Discrimination on the basis of race and ethnicity in the workplace has often been blatant and, while legislation protects against such discrimination, it still occurs; Black, Asian and ethnic minority (BAME) workers remain vulnerable to it. Acker (2006) argued that white men and women tend not to see their race privilege. Feeling under 'white scrutiny' at work and the need to prove themselves to be better than white male colleagues is a common experience of BAME workers (Healy et al., 2011; Tomlinson et al., 2013). Van Laer and Janssens (2011) demonstrate how subtle racial and ethnic discrimination can manifest itself in the workplace. Some people were found to be treated with some curiosity, yet although some questions addressed to ethnic minorities were positive, others had a judgemental undertone or the minority respondents felt they were treated in a condescending manner. Others spoke of how while they had been hired for their ethnic background, they did not feel their competencies 
were valued. This racialized undervaluing and undermining was also found by Healy et al. (2011), who spoke about how subtle discrimination can feel dangerous and may reinforce the notion that BAME people do not belong or do not want to integrate. Furthermore, minority ethnic groups tend not to achieve equal levels of career success when it comes to pay and career advancement, resulting in their cumulative disadvantage in managerial and professional careers (Ossenkop et al., 2015).

Van Laer and Janssens (2011) assert how subtle discrimination can involve the naturalization of intolerant and discriminatory behaviour and opinions. They argue how apparently tolerant ethnic majority individuals can be seen to approve and accommodate intolerant behaviour by other majority colleagues, which is revealed in various ways such as laughing at discriminatory jokes, or tolerating discriminatory behaviour from clients. Many employees therefore have to put up with offence and distress because of others' behaviours towards their race. Perhaps unsurprisingly, Healy et al. (2011) found various employees were reluctant to challenge the status quo for fear of being labelled 'troublemakers' or 'different', and so complied with organizational culture out of a sense of self-preservation. For example, Tomlinson et al. (2013) found that some of their respondents attempted to assimilate their behaviours (including dress, customs and hobbies) to conform to the dominant white masculine culture. Dress can be an indication of ethnic difference, with implications for workplace experiences of inclusion or exclusion (Kirton and Greene, 2016). Clothing can be a visible symbol of difference for people from different ethnic minorities (Healy et al., 2011). In recent times we have also witnessed the growing discrimination and concern related to the wearing of headscarves and accessories according to religious beliefs, and this too may impact upon the wearer's career and discrimination experienced in the workplace.

\section{Chapters on race}

Part V begins with Chapter 17, where Doyin Atewologun explores the experiences of Black, Asian and minority ethnic workers in professional service firms. Using a capital career framework, she looks at what it takes to make it to the top of such firms. She shows how career competencies interact and are transformed through time, influencing professional trajectories via multiple, intersecting diversity dimensions. Minority ethnic professional progress requires the successful acquisition and conversion of career competencies over time.

This is followed by Shirley Anne Tate and Naheed Arshad-Mather (Chapter 18), looking at the more specific experiences of Muslim women in the UK whose employment progression is shaped by the broader 
societal context of Islamophobia and racialized gendering, in addition to their experience, skills, aptitudes and qualifications. The authors consider the relationship between religion, race and gender, focusing on the impact of power, networks and values.

Following this is Chapter 19 by Dennis Foley, who looks at Aboriginal entrepreneurship as a commercial activity that is desperately needed as an economic alternative to improve the social positioning of Indigenous people. Success in entrepreneurship is a lifestyle change for not only the entrepreneur but also their immediate family, with direct and indirect impacts on the wider Aboriginal community.

Sammar Javed, Jawad Syed and Royce Turner (Chapter 20) take an in-depth look at the position of gender and careers in Pakistan. They discuss the position of women in the workforce and the barriers they face in their career development: for example, subjugation, segregation, education and belief system. They also note, however, that economic necessity, technological change and a trend to delay marriages are militating to promote female participation in economic activity, although they question whether these will sufficiently promote wider change in the economic structure.

\section{Part VI: Religion}

Religious harassment is deemed to occur when employees are required, or coerced, to participate in religious practices; are under pressure to conform to another's beliefs or to give up their own belief or practices; or are made to work in a hostile or offensive environment as a result of their religion (Ghumman et al., 2013). The provision of religious facilities and flexibility is a positive example of how equality and diversity policies can help employees to feel more integrated and valued, which should have a positive impact on their career experiences (Healy et al., 2011). However, the face of religion is changing, with increased religious diversity, increased religious expression, the integral role of religion in other aspects of life, and resultant legal ambiguities (Kelly, 2008). In the US this has resulted in a 96 per cent increase in claims of religious discrimination between 2000 and 2010 (Equal Employment Opportunity Commission, 2011), compared to 24 per cent for race, even though religious-based claims account for only 5 per cent of all discrimination claims reported to the Equal Employment Opportunity Commission. This is set to rise with global events, fuelled by individuals claiming to act in the name of Allah undertaking terrorist attacks, increasing religious discrimination. Such events are not only fuelling social violence (Pio, Chapter 22) but will also inevitably lead to negative effects in the 
workplace, creating a greater debate around whether beliefs are religious or secular (Ghumman et al., 2013).

The issue of religious 'nones' (Cragun et al., 2012) has also been raised in the literature and comes under the heading of religious discrimination. This includes those living by non-religious philosophical and ethical values, atheists and agnostics. The findings suggest that while religious people are generally aware of their new legal rights, they are often not sure how to go about pursuing them when needed, while 'non-religious' people often believe that the new legislation tends to privilege religious people, despite the legislative meaning of 'belief' including those living by non-religious philosophical and ethical values (Ghanea, 2012).

\section{Chapters on religion}

In Chapter 21, Yusuf Sidani begins Part VI by exploring the sensitive issue of the careers of veiled Muslim women (VMW) in Lebanon and the significant challenges and constraints experienced by those women. The chapter considers the social influences on career choices and how 'sealed borders' serve to inhibit the career development of veiled women. It concludes that the Lebanese working environment largely continues to adhere to a stereotype that VMW are not fit for most work arrangements.

This is followed by Edwina Pio's examination of the global position of Muslim women at work, using spatial, ontic and temporal perspectives (Chapter 22). She argues that the presence of religiously observant employees can create conflict at work, particularly when these observances may mean praying five times a day or wearing a face covering. She examines women's relationship to religion and its impact on their careers across 13 countries around the globe.

Shafaq Chaudhry and Vincenza Priola (Chapter 23) again visit the issue of the veil on careers, but this time with an ethnographical examination of women's career trajectory within a Western multinational bank and an Islamic bank in Pakistan. They show how organizational processes and patterns of work in the two banks are not only gendered and embedded in patriarchal systems, but are also heavily influenced by the organizational cultures that characterize these different banks. The chapter illustrates the qualitatively different regimes of gender inequalities in the banking sector.

Part VI is concluded by an innovative, novel chapter by Edwina Pio, Robert Kilpatrick and Timothy Pratt (Chapter 24) which explores the relationship between religion, callings and careers. Using three case studies to highlight whether a religion is necessary for a career to be a 
calling, they argue how religion gives structure to those on the career journey, and how their spirituality seeks for a sense of purpose in their 'calling'.

\section{Part VII: Sexuality}

Although society today is more accepting of sexual minorities than in previous decades, there is still social stigma attached to minority sexual groups, and this can have a massive impact on their experiences in the workplace. Ozturk and Tatli (2016) argue that gender identity as part of the lesbian, gay, bisexual, transgender, queer, intersex, asexual (LGBTQIA) category is marginalized as a diversity strand compared to other protected characteristics such as gender, race and ethnicity; while others claim that far more HRM research and practice into sexual minority employees is required (Bell et al., 2011; McFadden, 2015; McPhail et al., 2016; Syed, 2014). However, the concealment by some individuals of their sexual orientation can make it far more difficult to access participants for research purposes, and so we may not appreciate the full extent of their discrimination.

Organizations normalize and privilege heterosexuality, which can make the working environment quite alien for non-heterosexual employees. Dasgupta (2017) argues that non-heterosexuals need to engage with the heteronormative ideological expectations of corporate masculinity on a daily basis, having to work in traditional heterosexual social structures and adhere to social mores and morals, while potentially suffering homophobic environments. Heteronormative working environments are maintained in the way sexual minorities experience their work. For example, Ozturk and Rumens (2014) showed how LGBTQIA academics suffer employment discrimination in organizational procedures, and from students and colleagues. Similarly, Bell et al. (2011) argue how sexual minority voices are silenced by what is perceived as 'normal' in organizations, and that this can have negative consequences on individuals, including their fear of harassment, discrimination or dismissal, leading some to feel the need to conceal their sexuality for fear of negative repercussions. Having to hide one's non-work and social life is also fraught with problems, with decisions about disclosure being bound up with organizational policies and others' attitude in the workplace.

Priola et al. (2014) distinguish between formal discrimination on the basis of sexuality (that is, exclusions during recruitment and promotion processes, a lack of access to and distribution of resources), and informal discrimination, which refers to verbal and non-verbal behaviours on an interpersonal level (even as a witness) that restricts the respect, credibility 
and psychological well-being of sexual minorities. Worldwide there are varying levels of acceptance of homosexuality, and as companies become more global, this might impact on an individual's experiences at work, their career and their overall well-being. While in the West there may be increasing support of equal rights policies for LGBTQIA employees, they nevertheless still experience discrimination in the workplace which can be to the detriment of both themselves and their organizations. Being 'out' or 'open' in work can expose them to negative reactions, becoming victims of gossip and intrigue (Jepson and Fielden, Chapter 28). Some sexual minorities have told how they are asked personal questions about their sexual activities; something that is not likely to occur with heterosexual employees. The narratives of the respondents of Ozturk and Rumens (2014) show how others demean the issue of homosexuality, which can have negative outcomes including lowered levels of job satisfaction and psychological well-being (Griffith and Hebl, 2002). All the above difficulties show the cumulative negative impact these factors may have for LGBTQIA employees, and McFadden (2015) points to the limited research into 'newer' sexual and gender identities such as genderqueer, queer and intersex.

\section{Chapters on sexuality}

Mustafa Bilgehan Ozturk and Ahu Tatli (Chapter 25) begin Part VII by providing an insightful overview of the theories, concepts and evidence that underpin our understanding of sexual orientation, gender identity and careers in the workplace. They highlight the current career challenges faced by LGBTQI workers in planning and developing their careers, and explore possible remedial actions and pathways for improvement.

Fiona Gavin continues this theme in Chapter 26 by looking at the association between minority sexual orientation and social stigma, and how an identity might be concealed or revealed in the workplace. She explores this in relation to individuals' decisions whether or not to come 'out' at work, giving consideration to the psycho-social impact of such decisions for both the individual and the organization.

Fiona Colgan (Chapter 27) explores the opportunities and barriers to the career development of lesbian, gay and bisexual (LGB) employees in UK private sector organizations. Based on empirical research, this chapter considers how this development has encouraged and enhanced development opportunities to improve LGB visibility and voice in UK organizations. However, the author concludes that despite progress, barriers still exist in the career development of LGB employees.

Sandra Fielden and Hannah Jepson (Chapter 28) focus on lesbian careers, which can vary significantly from other LGBTQIA groups. They 
take an empirical approach, identifying key factors that influence lesbian careers: social climate, career choice, personality, work environment, and the intersection between gender and sexuality. They highlight that discrimination still occurs at work, but manifests itself in different and often more subtle ways, with one of the greatest challenges for lesbians being working within a heterosexist and heteronormative environment.

\section{Part VIII: Transgender}

Gender reassignment is the process of transitioning from one gender to another. This is a personal process, not a medical process. This means that someone does not need to have undergone surgery or be under any kind of medical supervision to be classed and protected as transgender. When an individual decides to live openly in their acquired gender, they have made a social transition (Law Society, 2015). However, transgender people are the most targeted minority group in relation to physical and psychological violence (Kidd and Witten, 2007). Unemployment rates for transgender individuals can be high, and Beauregard et al. (2016) outline how negative attitudes and behaviours towards trans individuals can be discriminatory, resulting in them leaving their jobs as they feel unsupported or threatened. Morton (2008) reveals how transgender respondents are highly qualified yet many earn very little. Moreover, more than half of those who were known as transgender at work experienced transphobic discrimination or harassment at work, while around one in six (15 per cent) said that their employer had failed to protect their privacy (Morton, 2008).

In the past, there has been a tendency to lump transgender individuals together into a 'gay' category, although there is now growing recognition that they should have a category of their own. Despite UK legislation for gender reassignment being first introduced in 1999, little research has been conducted on the workplace experiences of transgender individuals (Law et al., 2011; McFadden, 2015), let alone their career development. The original legislation has since been replaced by the UK Equality Act 2010, and discrimination on the basis of gender reassignment, gender identity and/or gender expression is prohibited by five directives. However, the whole experience of the workplace and managing one's career while transgender is a multifaceted process, as an individual struggles with discrimination and identity management (McFadden, 2015). Getting into organizations may be difficult, as a job applicant's CV may not contain some credentials or may have employment gaps, which may be perceived by potential employers as a lack of requisite education and job experience (Beauregard et al., 2016). Individuals may suffer specific 
difficulties in their career development during the transition phase (McFadden, 2015), and MacDonnell and Grigorovich (2012) recounted how some trans men needed to change their careers or jobs so that they could work in their chosen gender. Some transgender workers are subject to occupational segregation, clustering and even scattering (representing their tokenism) in the workplace (David, 2015).

Ozturk and Tatli (2016) explain that a range of workplace challenges are experienced by transgender employees as a result of a lack of acceptance, support and inclusion due to persistent stigmas around non-conforming gender identities. Such discrimination is not surprising when transgender people are rarely mentioned in organizations' diversity policies, statements or frameworks, demonstrating how these individuals' voices are unrepresented in the workplace (Beauregard et al., 2016) and how organizations fail to tackle discrimination on the basis of gender identity (Ozturk and Tatli, 2016). While workplace policies around dress codes, bathrooms and identity documents have been found to be of particular concern (Bender-Baird, 2011), others refer to the outright rejection that may be experienced by transgender employees (e.g., Collins et al., 2015), as well as physical threats, emotional abuse, interpersonal discrimination and stigmatization. Beauregard et al. (2016) argue that transgender voices are often unheard and this results in them being silenced and marginalized, which demonstrates a lack of commitment by employers to supporting trans employees and creating a fully inclusive workplace environment. Hence the authors claim that this lack of hearing such voices perpetuates issues to do with recruitment, retention and talent management issues for trans employees.

\section{Chapters on transgender}

In Chapter 29, Nick Rumens begins Part VIII and shows how trans people face formidable work and career-related challenges and barriers in the workplace. He uses queer theory as a lens through which to advance the academic debate on trans people's multiple desires and goals around gender transgression and congruency, work and careers. In doing so he considers how the performance of gender norms can shape career-related discrimination and opportunities experienced by transgender people,

Following on from this, Thomas Köllen (Chapter 30) provides an overview of the specific issues that trans persons face in their career development. For many transgender employees, the decision to initiate their transition brings with it a potential career setback and, quite often, a subsequent ongoing socio-economic decline. He illustrates this by highlighting the case of Andrea, a trans women who had her transition while she held a management position in a multinational organization. 
Chapter 31, by Helen Woodruffe-Burton, explores alternative career choices of female-to-male transgender individuals, looking at how they subjectively create and maintain their careers based on individual identity and personal values through empowerment, enterprise and resilience. She concludes that transgender is shown to be an enterprise as well as a calling. She shows how female-to-male transgender individuals have used resilience strategies and taken responsibility and control to generate their own personal values-driven protean careers, and are creative and dynamic in boundary crossing outside of traditional organizational structures.

Jackie Jones (Chapter 32) continues this theme by looking at the discrimination and prejudice suffered by the trans community. She explores the key barriers faced by trans people in the workplace and the lack of understanding in organizations around how those barriers impact on career progression. She concludes that although there are some signs of progress, the continued discrimination and harassment, lack of understanding, lack of policies directly targeted at trans workers as well as the lack of legal redress available, are all major barriers to their career progression.

\section{SUMMARY}

One of the resounding issues running through the issues of diversity within these chapters is the problem of intersectionality and multiple identities associated with numerous people in their careers. This makes diversity a double or triple bind for various people, which can have destructive effects on their careers and employment. It is well recognized that the concept of intersectionality (that is, the impact of multiple identities that occur within all individuals) plays a serious role in determining the extent to which an individual experiences discrimination. As disadvantage is socially constructed, it is important to recognize the impact of multiple identities on individuals (Haq, 2013), yet the UK Equality Act, section 14, only recognizes the combined discrimination of dual characteristics, that is, a combination of two relevant protected characteristics. Clearly this provides only limited protection for those who have more than two protected characteristics (Woodhams et al., 2015). For legislation that is aiming to afford protection to individuals from diverse groups, it is actually disadvantaging those who need it most, that is, those with multiple identities. In addition, the terminology itself creates and drives perceptions of diverse groups. For example, the term 'Black, Asian, minority, ethnic', or BAME, is still commonly used in policy circles and in the public domain. 
When considering workplace discrimination it appears that it is now less open and blatant, but remains in many organizations in a more subtle form. Legislation has no doubt helped to eradicate much blatant discrimination as such behaviours can be challenged on legal grounds. However, sometimes these are not easily challenged legally because of their less visible and more ambiguous nature. Subtle discrimination can be unconscious or unintentional, and 'entrenched in common, everyday interactions, taking the shape of harassment, jokes, incivility, avoidance, and other types of disrespectful treatment', and can produce feelings of disempowerment (Van Laer and Janssens, 2011, p. 1205). As such, it works to sustain the powerful position of the majority. Bell et al. (2011) contend that managing diversity and inclusion requires giving individuals a voice, so that their differences are recognized, and organizations can put in place measures to accommodate the differences in relation to decision-making and career development. This Handbook helps to provide such voice for individuals, and attempts to raise some of the issues relating to diversity and careers that remain to be addressed and resolved by organizations.

We have very much enjoyed working on this Handbook and with all the contributors. We hope that you too enjoy this unique collection of chapters and find the topic areas interesting, informative and thought-provoking.

\section{REFERENCES}

Acker, J. (1990), 'Hierarchies, jobs, bodies: a theory of gendered organizations', Gender and Society, 4 (2), 139-158.

Acker, J. (2006), 'Inequality regimes: gender, class and race in organizations', Gender and Society, 20 (4), 441-464.

Agars, M.D. (2004), 'Reconsidering the impact of gender stereotypes on the advancement of women in organizations', Psychology of Women Quarterly, 28 (2), 103-111.

Alvesson, M. and Billing, Y.D. (2009), Understanding Gender and Organizations, London: SAGE.

Anderson, D. and Vinnicombe, S. (2015), 'Senior women, work-life balance and the decision to quit: a generational approach', in A.M. Broadbridge and S.L. Fielden (eds), Handbook of Gendered Careers in Management: Getting In, Getting On, Getting Out, Cheltenham, UK and Northampton, MA, USA: Edward Elgar Publishing, pp. 445-459.

Arthur, M.B. (1994), 'The boundaryless career: a new perspective for organizational inquiry', Journal of Organizational Behavior, 15 (4), 295-306.

Baruch, Y. (2004), Managing Careers: Theory and Practice, London: FT Prentice Hall.

Baruch, Y. and Vardi, Y. (2016), 'A fresh look at the dark side of contemporary careers: towards a realistic discourse', British Journal of Management, 27 (2), 355-372.

Beauregard, T.A., Arevshatian, L., Booth, J.E. and Whittle, S. (2016), 'Listen carefully: transgender voices in the workplace', International Journal of Human Resource Management, DOI: 10.1080/09585192.2016.1234503. 
Bell, M.P., Özbilgin, M., Beauregard, T.A. and Surgevil, O. (2011), 'Voice, silence, and diversity in 21 st century organizations: strategies for inclusion of gay, lesbian, bisexual, and transgender employees', Human Resource Management, 50 (1), 131-146.

Bender-Baird, K. (2011), Transgender Employment Experiences: Gendered Perceptions and the Law, Albany, NY: SUNY Press.

Bendl, R. (2005), Revisiting Organization Theory: Integration and Deconstruction of Gender and Transformation of Organization Theory, Frankfurt: Peter Lang.

Bendl, R., Eberherr, H. and Schmidt, A. (2015), 'Inclusion and exclusion processes in the executive search business: an intersectional approach', in A.M. Broadbridge and S.L. Fielden (eds), Handbook of Gendered Careers in Management: Getting In, Getting On, Getting Out, Cheltenham, UK and Northampton, MA, USA: Edward Elgar Publishing, pp. 140-157.

Benschop, Y. and Doorewaard, H. (2012), 'Gender subtext revisited', Equality, Diversity and Inclusion: An International Journal, 31 (3), 225-235.

Billing, Y.D. (2015), 'Playing, quitting or changing the game? A discussion of women managers' responses to organizational conditions', in A.M. Broadbridge and S.L. Fielden (eds), Handbook of Gendered Careers in Management: Getting In, Getting On, Getting Out, Cheltenham, UK and Northampton, MA, USA: Edward Elgar Publishing, pp. 411-424.

Broadbridge, A. (2008), 'Senior careers in retailing: an exploration of male and female executives' career facilitators and barriers', Gender in Management: An International Journal, 23 (1), 11-35.

Broadbridge, A. (2009), 'Sacrificing personal or professional life? A gender perspective on the accounts of retail managers', International Review of Retail, Distribution and Consumer Research, 19 (3), 289-311.

Broadbridge, A.M. (2015), 'How some women achieve success', in A.M. Broadbridge and S.L. Fielden (eds), Handbook of Gendered Careers in Management: Getting In, Getting On, Getting Out, Cheltenham, UK and Northampton, MA, USA: Edward Elgar Publishing, pp. 258-274.

Brousseau, K.R., Driver, M.J., Eneroth, K. and Larsson, R. (1996), 'Career pandemonium: realigning organizations and individuals', Academy of Management Executive, 10 (4), 52-66.

Bruton, S. (2015), 'Looks-based hiring and wrongful discrimination', Business and Society Review, 120 (4), 607-635.

Carli, L.L. (2015), 'Women and leadership', in A.M. Broadbridge and S.L. Fielden (eds), Handbook of Gendered Careers in Management: Getting In, Getting On, Getting Out, Cheltenham, UK and Northampton, MA, USA: Edward Elgar Publishing, pp. 290-304.

Catalyst (2010), 'Changing workplaces, changing lives: women in management, global comparison', http://www.catalyst.org/publication/215/ (accessed 15 March 2010).

Cavico, F.J., Muffler, S.C. and Mujtaba, B.G. (2012), 'Appearance discrimination, "lookism" and "lookphobia" in the work-place', Journal of Applied Business Research (JABR), 28 (5), 791-802.

Collins, J.C., McFadden, C., Rocco, T.S. and Mathis, M.K. (2015), 'The problem of transgender marginalization and exclusion: critical actions for human resource development', Human Resource Development Review, 14 (2), 205-226.

Cragun, R.T., Kosmin, B.M., Keysar, A., Hammer, J.H. and Neilsen, M. (2012), 'On the receiving end: discrimination toward the non-religious in the United States', Journal of Contemporary Religion, 27 (1), 105-127.

Dasgupta, R. (2017), 'Acting straight? Non-heterosexual salarymen working with heteronormativity in the Japanese workplace', in X. Lin, C. Haywood and M. Mac an Ghaill (eds), East Asian Men: Masculinity, Sexuality and Desire, London: Palgrave Macmillan, pp. 31-50. 
David, E. (2015), 'Purple-collar labor: transgender workers and queer value at global call centers in the Philippines', Gender and Society, 29 (2), 169-194.

Davidson, M.J. and Fielden, S.L. (eds) (2003), Individual Diversity and Psychology in Organisations: A Handbook in the Psychology of Management in Organisations, Chichester: John Wiley \& Sons.

Dubbelt, L., Rispins, S. and Demerouti, E. (2016), 'Gender discrimination and job characteristics', Career Development International, 21 (3), 230-245.

Duncan, C. and Loretto, W. (2004), 'Never the right age? Gender and age-based discrimination in employment', Gender, Work and Organization, 11 (1), 95-115.

Eagly, A. and Carli, L.L. (2007), Through the Labyrinth: The Truth about how Women Become Leaders, Boston, MA: Harvard Business School Press.

Equal Employment Opportunity Commission (2011), 'Charge statistics FY 1997 through FY 2010', http://www.eeoc.gov/eeoc/statistics/enforcement/charges.cfm (accessed June 2017).

Etaugh, C.A. (2013), 'Midlife career transitions for women', in W. Patton (ed.), Conceptualising Women's Working Lives: Moving the Boundaries of Discourse, Rotterdam: Sense Publishers, pp. 105-118.

Frith, H. and Gleeson, K. (2008), 'Dressing the body: the role of clothing in sustaining body pride and managing body distress', Qualitative Research in Psychology, 5 (4), 249-264.

Fujmoto, Y., Rentscler, R., Le, H., Edwards, D. and Hartel, C.E.J. (2014), 'Lessons learned from community organizations: inclusion of people with disabilities and others', British Journal of Management, 25, 518-537.

Ghanea, N. (2012), 'Religious minorities and human rights: bridging international and domestic perspectives on the rights of persons belonging to religious minorities under English Law', European Yearbook of Minority Issues, 9, 497-518.

Ghumman, S., Ryan, A.M., Barclay, L.A. and Markel, K.S. (2013), 'Religious discrimination in the workplace: a review and examination of current and future trends', Journal of Business Psychology, 28, 439-454.

Granleese, J. and Sayer, G. (2005), 'Gendered ageism and lookism: a triple jeopardy for female academics', Women in Management Review, 21 (6), 500-517.

Griffith, K.H. and Hebl, M.R. (2002), 'The disclosure dilemma for gay men and lesbians: "coming out" at work', Journal of Applied Psychology, 87 (6), 1191-1199.

Hall, D.T. (1976), Careers in Organizations, Santa Monica, CA: Goodyear Publishing Company.

Hall, D.T. (1996), 'Introduction: long live the career. a relational approach', in D.T. Hall and Associates (eds), The Career is Dead, Long Live the Career: A Relational Approach to Careers, San Francisco, CA: Jossey-Bass, pp. 1-20.

Halryno, S. (2009), 'Men's work-life conflict: career, care and self realization: patterns of privileges and dilemmas', Gender, Work and Organization, 16 (1), 98-125.

Hanappi-Egger, E. (2015), 'Gender scripts as access codes to management positions', in A.M. Broadbridge and S.L. Fielden (eds), Handbook of Gendered Careers in Management: Getting In, Getting On, Getting Out, Cheltenham, UK and Northampton, MA, USA: Edward Elgar Publishing, pp. 61-73.

Haq, R. (2013), 'Intersectionality of gender and other form of identity: dilemmas and challenges facing women in India', Gender in Management: An International Journal, 28 (3), 171-184.

Haynes, K. (2017), 'Accounting as gendering and gendered: a review of 25 years of critical accounting research on gender', Critical Perspectives on Accounting, 43, $110-124$.

Healy, G., Bradley, H. and Forson, C. (2011), 'Intersectional sensibilities in analysing inequality regimes in public sector organizations', Gender, Work and Organization, 18 (5), 467-487. 
Hearn, J. (2004), 'From hegemonic masculinity to the hegemony of men', Feminist Theory, 5 (1), 49-72.

Heilman, M.E. (2001), 'Description and prescription: how gender stereotypes prevent women's ascent up the organizational ladder', Journal of Social Issues, 67 (4), 657-674.

Heilman, M.E., Manzi, F. and Braun, S. (2015), 'Presumed incompetent: perceived lack of fit and gender bias in recruitment and selection', in A.M. Broadbridge and S.L. Fielden (eds), Handbook of Gendered Careers in Management: Getting In, Getting On, Getting Out, Cheltenham, UK and Northampton, MA, USA: Edward Elgar Publishing, pp. 90104.

Holgersson, C. (2013), 'Recruiting managing directors: doing homosociality', Gender, Work and Organization, 20 (4), 454-466.

Holton, V. (2015), 'Women managers, careers and organisations', in A.M. Broadbridge and S.L. Fielden (eds), Handbook of Gendered Careers in Management: Getting In, Getting On, Getting Out, Cheltenham, UK and Northampton, MA, USA: Edward Elgar Publishing, pp. 243-257.

Holvino, E. (2008), 'Intersections: the simultaneity of race, gender and class in organization studies', Gender, Work and Organization, 17 (3), 248-277.

Howlett, N., Pine, K.J., Cahill, N., Orakciogiu, I. and Fletcher, B. (2015), 'Unbuttoned: the interaction between provocativeness of female work attire and occupational status', Sex Roles, 72 (3), 105-116.

Jyrkinen, M. (2014), 'Women managers, careers and gendered ageism', Scandinavian Journal of Management, 30, 175-185.

Kanter, Rosabeth M. (1977), Men and Women of the Corporation, New York: Basic Books.

Karl, K., Hall, L.M. and Peluchette, J. (2013), 'City employee perceptions of the impact of dress and appearance: you are what you wear', Public Personal Management, 42 (3), 452-470.

Kelan, E. (2013), 'The becoming of business bodies: gender, appearance and leadership development', Management Learning, 44 (1), 45-61.

Kelly, E. (2008), 'Accommodating religious expression in the workplace', Employee Responsibilities and Rights Journal, 20, 45-56.

Kerfoot, D. and Knights, D. (1993), 'Management, masculinity and manipulation: from paternalism to corporate strategy in financial services in Britain', Journal of Management Studies, 30 (4), 659-677.

Kidd, J.D. and Witten, T.M. (2007) 'Transgender and transsexual identities: the next strange fruit - hate crimes, violence and genocide against the global transcommunities', Journal of Hate Crimes, 6 (1), 361-663.

King, E.B., Ahmad Koch, M., Forgues, B. and Monties, V. (2017), 'The way to the top: career patterns of Fortune 100 CEOs', Human Resource Management, 56 (2), 267-285.

Kirton, G. and Greene, A.M. (2016), The Dynamics of Managing Diversity: A Critical Approach, London: Routledge.

Kumra, S. (2010), 'The social construction of merit in a professional services firm: what is in and who is out?', British Academy of Management Annual Conference, Sheffield, 14-16 September.

Kumra, S. and Manfredi, S. (2012), Managing Equality and Diversity: Theory and Practice, Oxford: Oxford University Press.

Law, C.L., Martinez, L.R., Ruggs, E.N., Hebl, M.R. and Akers, E. (2011) 'Trans-parancy in the workplace: how the experiences of transsexual employees can be improved', Journal of Vocational Behavior, 79, 710-723.

Law Society (2015), 'Working with transgender employees', http://www.lawsociety.org.uk/ Support-services/Advice/Practice-notes/working-with-transgender-employees/ (accessed 30 January 2017).

Levin, L., Mattis, M., Tsentides, A. and Beier, J. (2015), 'Pursuing partnerships: flexible working arrangements in US accounting ad law firms', in A.M. Broadbridge and 


\section{Research handbook of diversity and careers}

S.L. Fielden (eds), Handbook of Gendered Careers in Management: Getting In, Getting On, Getting Out, Cheltenham, UK and Northampton, MA, USA: Edward Elgar Publishing, pp. 327-373.

Lewis, K.V., Harris, C., Morrison, R. and Ho, M. (2015), 'The entrepreneurshipmotherhood nexus: a longitudinal investigation from a boundaryless career perspective', Career Development International, 20 (1), 21-37.

MacDonnell, J.A. and Grigorovich, A. (2012), 'Gender, work, and health for trans health providers: a focus on transmen', ISRN Nursing, DOI:10.5402/2012/161097.

Maddox-Daines, K. (2016), 'Mid-career as a process of discovery', Career Development International, 21 (1), 45-59.

Mainiero, L.A. and Sullivan, S.E. (2005), 'Kaleidoscope careers: an alternative explanation for the "opt-out" revolution', Academy of Management Executive, 19 (1), 106-123.

Mallon, M. (1998), 'The portfolio career: pushed or pulled to it?', Personnel Review, 27 (5), 361-377.

Mavin, S., Williams, J., Bryans, P. and Patterson, N. (2015), “Woman as a project": key issues for women who want to get on', in A.M. Broadbridge and S.L. Fielden (eds), Handbook of Gendered Careers in Management: Getting In, Getting On, Getting Out, Cheltenham, UK and Northampton, MA, USA: Edward Elgar Publishing, pp. 305-321.

McElroy, J.C., Summers, J.K. and Moore, K. (2014), 'The effect of facial piercing on perceptions of job applicants', Organizational Behavior and Human Decision Processes, 125 (1), 26-38.

McFadden, C. (2015), 'Lesbian, gay, bisexual, and transgender careers and human resource development: a systematic literature review', Human Resource Development Review, 14 (2), 125-162.

McPhail, R., McNulty, Y. and Hutchings, K. (2016), 'Lesbian and gay expatriation: opportunities, barriers and challenges for global mobility', International Journal of Human Resource Management, 27 (3), 382-406.

Morton, J. (2008), 'Transgender experiences in Scotland', Research summary, Edinburgh: Scottish Transgender Alliance, http://www.scottishtrans.org/wp-content/uploads/2013/ 03/staexperiencessummary03082.pdf (accessed 15 May 2017).

Mountford, H. and Murray, P.A. (2015), 'Age diversity in the workplace', in J. Syed and M. Özbilgin (eds), Managing Diversity and Inclusion: An International Perspective, London: SAGE, pp. 191-214.

Murphy, W.M. and E.H. Volpe (2015), 'Encore careers: motivating factors for career exit and rebirth', in A.M. Broadbridge and S.L. Fielden (eds), Handbook of Gendered Careers in Management: Getting In, Getting On, Getting Out, Cheltenham, UK and Northampton, MA, USA: Edward Elgar Publishing, pp. 425-444.

Nafukho, F.M., Roessler, R.T. and Kacirek, K. (2010), 'Disability as a diversity factor: implications for human resource practices', Advances in Developing Human Resources, 12 (4), 395-406.

Oakley, J.G. (2000), 'Gender-based barriers to senior management positions: understanding the scarcity of female CEOs', Journal of Business Ethics, 27, 321-334.

Office for Disability Issues (2014), 'Disability facts and figures', https://www.gov.uk/ government/statistics/disability-facts-and-figures (accessed 2 June 2017).

O’Neil, D.A. and Bilimoria, D. (2005), 'Women's career development phases: idealism, endurance, and reinvention', Career Development International, 10 (3), 168-189.

O'Neil, D.A., Hopkins, M.M. and Bilimoria, D. (2013), 'Patterns and paradoxes in women's careers', in W. Patton (ed.), Conceptualising Women's Working Lives: Moving the Boundaries of Discourse, Rotterdam: Sense Publishers, pp. 63-79.

Ossenkop, C., Vinkenburg, C.J., Jansen, P.G.W. and Ghorashi, H. (2015), 'Ethnic diversity and social capital in upward mobility systems: problematizing the permeability of intra-organizational career boundaries', Career Development International, 20 (5), $539-558$. 
Özbilgin, M.F. and Chanat, J.-F. (2017), Management and Diversity: Perspectives from Different National Contexts, Bingley: Emerald.

Ozturk, M. and Rumens, N. (2014), 'Gay male academics in UK business and management schools: negotiating heteronormativities in everyday work life', British Journal of Management, 25, 503-517.

Ozturk, M. and Tatli, A. (2016), 'Gender identity inclusion in the workplace: broadening diversity management research and practice through the case of transgender employees in the UK', International Journal of Human Resource Management, 27 (8), 781-802.

Peiperl, M. and Baruch, Y. (1997), 'Back to square zero: the post corporate career', Organizational Dynamics, 25 (4), 7-22.

Peluchette, J. and Karl, K. (2007), 'The impact of workplace attire on employee self-perceptions', Human Resource Development Quarterly, 18 (3), 345-360.

Peluchette, J., Karl, K. and Rust, K. (2006), 'Dressing to impress: beliefs and attitudes regarding workplace attire', Journal of Business and Psychology, 21 (1), 45-63.

Powell, G.N. (2012), 'Six ways of seeing the elephant: the intersection of sex, gender, and leadership', Gender in Management: An International Journal, 27 (2), 119-141

Powell, G.N. and Mainiero, L.A. (1992), 'Cross-currents in the river of time: conceptualizing the complexities of women's careers', Journal of Management, 18 (2), 215-237.

Prime, J., Jonsen, K., Carter, N. and Maznevski, M.L. (2008), 'Managers' perceptions of women and men leaders: a cross cultural comparison', International Journal of Cross Cultural Management, 8 (2), 171-210.

Priola, V., Lasio, D., DeSimone, S. and Serri, F. (2014), 'The sound of silence: lesbian, gay, bisexual and transgender discrimination in "inclusive organizations", British Journal of Management, 25, 488-502.

Reynolds, G., Nicholls, P. and Alferoff, C. (2001), 'Disabled people, (re)training and employment: a qualitative exploration of exclusion', in M. Noon and E. Ogbonna (eds), Equality, Diversity and Disadvantage in Employment, Basingstoke: Palgrave, pp. 172189.

Ryan, M.K. and Haslam, S.A. (2005), 'The glass cliff: evidence that women are over-represented in precarious leadership positions', British Journal of Management, 16 (2), 81-90.

Schein, V. (2001), 'A global look at psychological barriers in management', Journal of Social Issues, 57 (4), 675-688.

Schein, V.E. (1975), 'Relationships between sex roles stereotypes and requisite management characteristics', Journal of Applied Psychology, 60 (3), 340-344.

Sealy, R. and Singh, V. (2010), 'The importance of role models and demographic context for senior women's work identity development', International Journal of Management Reviews, 12 (3), 284-230.

Simpson, M., Richardson, M. and Zorn, T.E. (2012), 'A job, a dream or a trap? Multiple meanings for encore careers', Work, Employment and Society, 26 (3), 429-446.

Sullivan, S.E. and Baruch, Y. (2009), 'Advances in career theory and research: a critical review and agenda for future exploration', Journal of Management, 35 (6), 1542-1571.

Super, D.E. (1957), The Psychology of Careers, New York: Harper \& Row.

Swami, V., Stieger, S., Pietschnig, J., Voracek, M., Furnham, A. and Tovee, M.J. (2012), 'The influence of facial piercings and observer personality on perceptions of physical attractiveness and intelligence', European Psychologist, 17 (3), 213-221.

Syed, J. (2014), 'Diversity management and missing voices', in A. Wilkinson, J. Donaghey, T. Dundon and R. Freeman (eds), Handbook of Research on Employee Voice, Cheltenham, UK and Northampton, MA, USA: Edward Elgar Publishing, pp. 421-438.

Tatli, A. and Özbilgin, M.F. (2012), 'An emic approach to intersectional study of diversity at work: a Bourdieuan framing', International Journal of Management Reviews, 14 (2), 180-200. 
Tienari, J., Meriläinen, S., Holgersson, C. and Bendl, R. (2013), 'And then there are none: on the exclusion of women in processes of executive search', Gender in Management: An International Journal, 28 (1), 43-62.

Timmings, A.R., Nickson, D., Re, D. and Perrett, D. (2017), 'What do you think of my ink? Assessing the effects of body art on employment chances', Human Resource Management, 56 (1), 133-149.

Tomlinson, J., Muzio, D., Sommerlad, H., Webley, L. and Duff, L. (2013), 'Structure, agency, and career strategies of white women and black and minority ethnic individuals in the legal profession', Human Relations, 66 (2), 245-269.

United Nations (2015), 'World population prospects: the 2015 revision, key findings and advance tables', Working Paper No. ESA/P/WP.241, Department of Economic and Social Affairs, Population Division, https://esa.un.org/unpd/wpp/publications/files/key_ findings_wpp_2015.pdf (accessed 2 May 2017).

Vanderbroeck, P. (2010), 'The traps that keep women from reaching the top and how to avoid them', Journal of Management Development, 29 (9), 764-770.

Van Laer, K. and Janssens, M. (2011), 'Ethnic minority professionals' experiences with subtle discrimination in the workplace', Human Relations, 64 (9), 1203-1227.

Wajcman, J. (1996), 'Women and men managers: careers and equal opportunities', in R. Crompton, D. Gallie and K. Purcell (eds), Changing Forms of Employment: Organisations, Skills and Gender, London: Routledge, pp. 259-277.

Wajcman, J. (1998), Managing Like a Man, Oxford: Polity Press.

Walker, J.W. (1992), 'Career paths in flexible organizations', in D.H. Montross and C.J. Shinkman (eds), Career Development: Theory and Practice, Springfield, IL: Charles C. Thomas, pp. 385-402.

Warhurst C., van den Broek, D., Nickson, D. and Hall, R. (2012), 'Great expectations: gender, looks and lookism at work', International Journal of Work, Organization and Emotion, 5 (1), 72-90.

Wellington, S., Brumit Kropf, M. and Gerkovich, P.R. (2003), 'What's holding women back?', Harvard Business Review, 81 (6), 18-19.

Wettstein, F. (2009), 'Beyond voluntariness, beyond CSR: making a case for human rights and justice', Business and Society Review, 114 (1), 125-162.

Wood, G. (2009), 'Revisiting women managers and organisational acceptance', Gender in Management: An International Journal, 24 (8), 615-631.

Woodhams, C., Lupton, B. and Cowling, M. (2015), 'The snowballing penalty effect: multiple disadvantages and pay', British Journal of Management, 23, 63-77.

Yates, J., Hooley, T. and Bagri, K.K. (2016), 'Good looks and good practice: the attitudes of career practitioners to attractiveness and appearance', British Journal of Guidance and Counselling, https://doi.org/10.1080/03069885.2016.1237615.

Zimmerman, L.M. and Clark, M.A. (2016) 'Opting-out and opting in: a review and agenda for future research', Career Development International, 21 (6), 603-633. 